\title{
İç Anadolu Bölgesi tarım topraklarının bazı verimlilik parametrelerinin belirlenerek haritalanması
}

\section{Assessment and mapping of soil fertility in Central Anatolian croplands}

\author{
Alper AKIN \\ Gübretaş Ar-Ge Merkezi, Atalar Mh. Hayat Sk. No: 3041740 Körfez, Kocaeli \\ Sorumlu yazar (Corresponding author): A. Akın, e-posta (e-mail): aakin@gubretas.com.tr \\ Yazar(lar) e-posta (Author e-mail): htasova@gubretas.com.tr
}

\section{MAKALE BILGISİ}

Alınış tarihi 12 Mart 2019

Düzeltilme tarihi 19 Nisan 2019

Kabul tarihi 26 Nisan 2019

\section{Anahtar Kelimeler:}

CBS

İç Anadolu Bölgesi

Toprak veri tabanı

Toprak haritası

\begin{abstract}
ÖZ
$\mathrm{Bu}$ araştırma, İç Anadolu Bölgesi tarım topraklarında, bitki besin maddesi kapsamlarının belirlenmesi ve coğrafi bilgi sistemleri kullanılarak güncel toprak veri tabanlarının oluşturularak haritalanması amacıyla yapılmıştır. Toprak numuneleri 0-30 $\mathrm{cm}$ derinlikten alınmış ve örnekleme noktalarının koordinatları kaydedilmiştir. Alınan 2672 adet toprak örneğinde bünye, $\mathrm{pH}$, toplam tuz, kireç, organik madde, mevcut mikro ve makro elementler analiz edilmiştir. Bu numunelerin analiz sonuçlarına göre, bitki besin maddeleri eksiklik, yeterlilik ya da fazlalık açısından sınıflandırılmıș ve değerlendirilmiștir. Ardından CBS teknikleri kullanılarak çalışma alanının bir veri tabanı oluşturulmuş ve toprak verimliliği haritaları üretilmiştir. Araştırma sonucuna göre, İç Anadolu Bölgesi topraklarının \%75.9'unu killi tınlı ve tınlı topraklar oluşturmaktadır. Bölge topraklarının \%89.2'sini hafif alkali ve \%99.4'ünü ise tuzsuz topraklar oluşturmaktadır. Organik madde kapsamı açısından bölge topraklarının \%85.5'i az ve çok az sınıfındadır. Bölge topraklarının \%56.1'i fazla ve çok fazla kireçlidir. Yarayışılı fosfor kapsamı bakımından bölge topraklarının \% 75.4 'ü orta, az ve çok az sınıfındadır. Yarayışlı potasyum kapsamı bakımından ise, bölge topraklarının \%94.4'ü fazla sınıfındadır. İç Anadolu Bölgesi topraklarının değişebilir kalsiyum miktarlarının \%99.2'si ve değişebilir magnezyum miktarlarının \%93.4'ü yeterli, fazla ve çok fazla düzeyindedir. Bölge topraklarının yarayıșlı demir, çinko ve mangan kapsamları sırasıyla \%44.8'i, \%75.3’ü ve \%92.3'ü az ve çok az sınıfındadır. Yarayışlı bakır kapsamları bakımından ise bölge topraklarının \%98.8'i yeterli düzeydedir.
\end{abstract}

\section{ARTICLE INFO}

Received 12 March 2019

Received in revised form 19 April 2019 Accepted 26 April 2019

\section{Keywords:}

GIS

Central Anatolia

Soil database

Soil map

\begin{abstract}
The purpose of this study was to determine the current status of soil nutrient content, creating an actual soil nutrient database and mapping of agricultural lands in Central Anatolian using Geographical Information Systems (GIS). Soil samples were taken from 0-30 cm depth and the coordinates of the sampling points were recorded. In 2672 soil samples taken, soil texture, $\mathrm{pH}$, total soil salinity, calcium carbonate, organic matter, available micro and macro elements were analyzed. Analysis results of these samples were classified and evaluated for deficiency, sufficiency or excess in respect of plant nutrients. Then, a database of the study area was created by using GIS techniques and soil fertility maps were produced. According to the results, $75.9 \%$ of the region is composed of clay loam and loamy soils. $89.2 \%$ of the region is composed of slightly alkaline and $99.4 \%$ is composed of non salty soils. In terms of organic matter, $85.5 \%$ of the region is low and very low. $56.1 \%$ of the region is high and very high calcareous. In terms of the available phosphorus content, $75.4 \%$ of the region is moderate, low and very low class. In terms of available potassium content, $94.4 \%$ of the region is in excess. $99.2 \%$ of the exchangeable calcium content and $93.4 \%$ of the exchangeable magnesium content of the region is sufficient, high and very high. Respectively, $44.8 \%, 75.3 \%$ and $92.3 \%$ of the available iron, zinc and manganese contents of the region are classified as low and very low. $98.8 \%$ of the region is sufficient in terms of the available copper.
\end{abstract}

\section{Giriş}

Bitkilerin sağlıklı gelişmesi ve hastalıklardan korunması için dengeli beslenmesi gerekmektedir. Özellikle tek yanlı gübre kullanımı, bitkilerde beslenme bozukluklarına yol açmakta ve ayrıca topraktaki bitkiye elverişli diğer besin maddelerinin bitki 
tarafından alınımını engellemektedir. Bu nedenle gübrelemenin uygun miktar, zaman ve metotla yapılmas1 gerekmektedir. Bu anlamda, birim alandan elde edilen gelirin arttırılmasinda temel koşul; verim artırıcı yeni teknoloji ve tarımsal uygulamaların doğru bir şekilde uygulanarak verimin arttırılması ve bunun yanında enerji gereksinimi ve işgücünün düşürülmesidir.

Ülkemizdeki hızlı nüfus artışına paralel olarak, tarım ürünlerine olan ihtiyacımız da giderek artmaktadır. Buna karşılık, üretim ortamı olan toprak ve arazi varlığımızda herhangi bir artış olmadığı gibi, amaç dışı kullanımlarla mevcut tarım arazileri miktarı da azalmaktadır (TÜIK 2018). Nüfusun hızla artması insanları yeni kaynaklar aramaya, mevcut kaynakları daha ekonomik kullanmaya ve yeni teknolojilere yönelmeye zorlamaktadır. Artan nüfusun besin ihtiyacını karşılamak amacıyla yapılan çalışmaların başında, birim alandan daha fazla ve daha kaliteli ürün elde etmeye yönelik çalışmalar gelmektedir.

Sürdürülebilir tarımsal üretim açısından, toprak özelliklerinin periyodik olarak belirlenmesi ve bunların toprak yönetimindeki değişikliklere verdikleri tepkilerin tespit edilmesi önemlidir. Toprak verimliliğini etkileyen çeşitli parametrelerin, mekânsal dağılımlarının CBS kapsamında değerlendirilerek haritalanmas1, toprakların günümüzdeki ve gelecekteki kullanımları için önemli bilgileri ortaya koymaktadır.

Günümüzde hala kullanılan ilk toprak verileri, (Mülga) TOPRAKSU Genel Müdürlüğü tarafindan 1966-1971 yılları arasında tüm ülke topraklarını kapsayan toprak etütleri ve 1/25 000 ölçekli topoğrafik haritalar kullanılarak oluşturulan haritalardır. Bundan sonra, 1/25 000 ölçekli haritalardan, 67 ilin her biri için 1/100 000 ölçekli Toprak Kaynağı Envanter Haritası ve Raporu yayınlanmıştır. 1982-1984 yılları arasında "Türkiye Toprak Potansiyeli Etütleri ve Tarım Dışı Amaçlı Arazi Kullanımı Planlamaları" projesi ile bu çalışma yeniden revize edilerek 1/100 000 ölçekli "İl Arazi Varlığı" olarak yayınlanmıştır. Türkiye topraklarının verimlilik envanterlerinin çıartılmasına yönelik olarak gerçekleştirilen "Türkiye Topraklarının Verimlilik Envanteri Projesi” ile ülke topraklarının özellikle üst toprak katının bazı fiziksel ve kimyasal özellikleri belirlenerek haritalanmıştır (TOVEP 1991). Birçok kurum ve kuruluşun başvurduğu, temel kaynak niteliğindeki bu çalışmalardan sonra, özellikle son yıllarda ülkemizdeki çeşitli kurumlar tarafindan yürütülen bazı çalışmalar ulusal toprak kaynakları açısından önemli bir veri tabanı oluşturmaktadır.
Ulusal anlamda planlamalar yapılmadan önce ülke kaynaklarının bir envanterinin çıkartılması ve eldeki kaynakların potansiyellerinin saptanması ve bu potansiyellere uygun kullanılması öncelikli konuların başında gelmektedir. Bu nedenle, bu çalışma İç Anadolu Bölgesi topraklarının verimlilik durumunu değerlendirmek ve bazı toprak verimliliği parametrelerinin, mekânsal değişkenliğini haritalamak amacıyla yapılmıştır.

\section{Materyal ve Yöntem}

\subsection{Materyal}

Araştırma, Aksaray, Ankara, Çankırı, Eskişehir, Karaman, Kayseri, Kırıkkale, Kırşehir, Konya, Nevşehir, Niğde, Sivas ve Yozgat illerindeki büyük toprak gruplarında, tarım yapılan alanlarda yürütülmüştür. İç Anadolu Bölgesi'nin yüz ölçümü $151000 \mathrm{~km}^{2}$ olup, toplam 7781000 hektar tarım alanına sahiptir. Yıllık yağışın 300-400 mm ve uzun yıllar sıcaklık ortalamasının $10-12{ }^{\circ} \mathrm{C}$ olduğu bölge topraklarının büyük bölümünü, kahverengi topraklar oluşturmaktadır. Bunun yanında kireçsiz kahverengi topraklar, regosol ve alüvyal topraklar da görülmektedir (TOVEP 1983, 1984, 1985). Ağırlıklı olarak bölgede, hububat, şekerpancarı, patates, ayçiçeği ve mısır tarımı yapılmaktadır.

\subsection{Yöntem}

$\mathrm{Bu}$ araştırma; arazi, laboratuvar ve haritalama çalışmalarını içeren başlica üç aşamada yürütülmüştür. Toprak örneği almak amacıyla yapılan büro çalışması ve arazi etütlerinde; illerin $1 / 25000$ ölçekli topoğrafik ve toprak haritaları ile 1/100 000 ölçekli TOVEP projesi ve Arazi Varlığı haritalarından faydalanılmıştır. Toprak örnekleme noktalarını belirlemek için, sayısal 1/25000 ölçekli toprak haritaları ile arazi kullanım bilgileri ArcGIS yazılımı kullanılarak sorgulanmış ve tarım alanları katmanı elde edilmiştir. Toprak örnekleri tarım arazilerinden 4-5 km aralıklarla, 2672 farklı noktadan, genel kurallara uygun olarak, Jackson (1958)'e göre, 0-30 cm derinlikten paslanmaz çelik kürek ile alınmış ve bez torbalara konularak analizlerinin yapılması için muhafaza edilmiştir. Toprak örneği alınan yerlerin yer koordinatları ve deniz seviyesinden yüksekliği GPS ile belirlenmiştir. Alınan toprak örneklerinin yerleri Şekil 1'de gösterilmiştir.

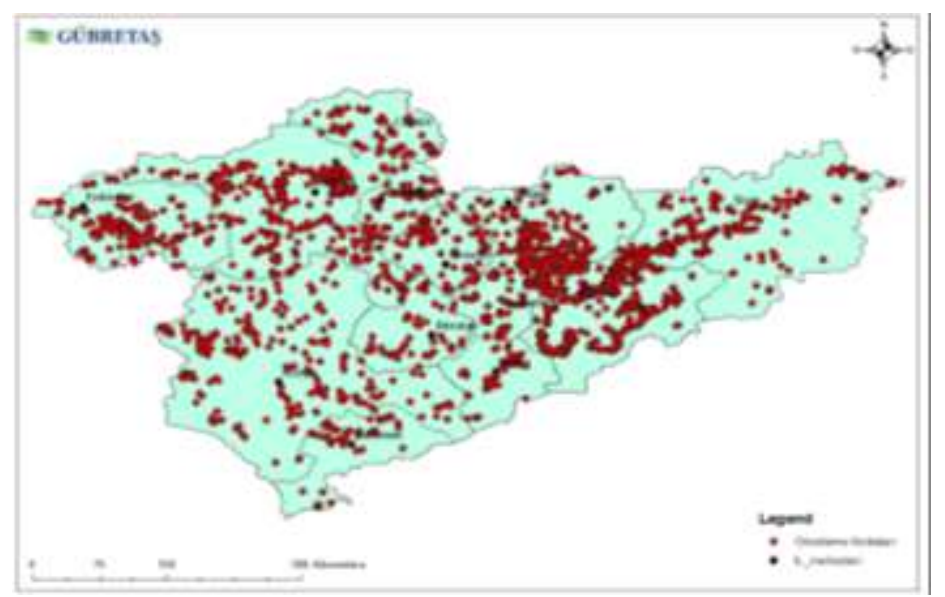

Şekil 1. İç Anadolu Bölgesinden alınan toprak örneklerinin konumları.

Figure 1. Location of soil samples taken from Central Anatolia Region. 


\subsubsection{Toprakların verimlilik analiz yöntemleri}

Laboratuvara getirilen toprak örnekleri, temiz kâğıt üzerine serilerek, taş ve bitki parçacıkları ayıklanarak, havada kurumaya bırakılmıştır. Kuruyan topraklar dövülerek $2 \mathrm{~mm}$ 'lik plastik elekten geçirilmiştir (Kacar 2009). Elenen toprak örneklerinde; bünye analizleri, Richards (1954)'e göre, toprağa doyuncaya kadar saf su ilave edilmek suretiyle bulunmuştur. Toprak reaksiyonu, hazırlanan saturasyon çamurunda, cam elektrotlu pH metre ile ölçülmüştür (Richards 1954). Ölçülen pH değerleri Ülgen ve Yurtsever (1995)'e göre sınıflandırılmıştır. Toprakların toplam tuz içerikleri, kondüktivite cihazı ile suyla doygun toprakta elektriksel iletkenliğin ölçülmesi suretiyle tayin edilerek (Richards 1954), belirlenmiş ve \% olarak ifade edilmiştir. Toprak örneklerinin $\mathrm{CaCO} 3$ içerikleri Çağlar (1949)'a göre, Scheibler kalsimetresinde işleme tabi tutulması ile belirlenerek \% olarak ifade edilmiştir. Toprakların organik madde içerikleri, modifiye edilmiş Walkley-Black yöntemiyle belirlenmiş ve \% olarak ifade edilmiştir (Jackson 1958). Toprak örneklerin yarayışlı fosfor içerikleri, $0.5 \mathrm{M} \mathrm{NaHCO}_{3}$ ekstraksiyonu ile belirlenmiştir (Olsen ve ark. 1954). Toprak örneklerinin bitkiye yarayışlı potasyum, kalsiyum ve magnezyum içerikleri, $1 \mathrm{~N}$ Amonyum Asetat ekstraksiyonunda ICP ile ölçülmek suretiyle tespit edilmiştir (Richards 1954). Araştırma topraklarının bitkiye yarayışlı mikro element $(\mathrm{Fe}, \mathrm{Cu}$, Zn, Mn ) içerikleri ise Lindsay ve Norvell (1978)'e göre, DTPA + TEA ile ekstrakte edildikten sonra, elde edilen süzüklerdeki $\mathrm{Fe}, \mathrm{Cu}, \mathrm{Zn}$ ve $\mathrm{Mn}$ miktarları ICP'de okunarak tayin edilmiştir.

\subsubsection{Istatistik analiz, veri tabanının oluşturulması ve dă̆llım haritalarının oluşturulması}

Projenin üçüncü aşamasında; toprak analiz sonuçlarından elde edilen verilerin Coğrafi Bilgi Sistemleri kapsamında değerlendirilmesi, analiz edilmesi, veri tabanının oluşturulması ve haritalanması işlemleri gerçekleştirilmiştir. Toprak örneklerindeki makro element toprak analiz sonuçları, Toprak Gübre ve Su Kaynakları Araştırma Enstitüsü veri kriterlerine göre, mikro element toprak analiz sonuçları ise Lindsay ve Norvell (1978)'e göre sinıflandırılarak, besin maddelerinin eksiklik, yeterlilik veya fazlalık seviyeleri belirlenmiș ve sınır değerlerine göre dağılım oranları hesaplanarak yorumlanmıştır. Toprak özelliklerinin dağılım durumlarının belirlenmesinde, IDW ve Kriging enterpolasyon yöntemlerini karş1laştırmak, ölçülen değerler ile tahmin edilen değerler arasındaki ilişkiyi sorgulayabilmek ve en uygun yöntemi seçebilmek için karesel ortalama hata (RMSE) yöntemi esas alınmıştır. En düşük RMSE değeri IDW tekniği ile elde edildiği için dağılımlar bu teknik ile belirlenmiştir. Bu kapsamda değişik toprak özelliklerine ait analiz sonuçları değerlendirilerek haritalanmıştır (Yomralığlu 2000).

\section{Bulgular}

İç Anadolu Bölgesi tarım alanlarından alınan toprak örneklerinin analiz sonuçlarına ait tanımlayıcı istatistikler Çizelge 1'de verilmiştir. Çizelge 1'de verilen çarpıklık katsayıları incelendiğinde, Ca dışındaki kimyasal özelliklerin normal dağılımdan uzak pozitif dağılımlar gösterdiği, bünye, kireç, organik madde, K2O ve Mg'nin kabul edilebilir $( \pm 2)$ çarpıklık katsayısı gösterdiği belirlenmiştir. Pozitif çarpıklık katsayıları, incelenen kimyasal toprak özelliklerinin ortalamanın üzerinde aşırı uç değerlere sahip olduğunu açıklamaktadır (Özyazıcı ve ark. 2015). Toprak özelliklerinin pek çoğunda çıkan bu uç değerlerin varlığı, varyasyon katsayılarının yüksek bulunmasıyla da desteklenmektedir. Toprak özelliklerindeki değişimlerin açıklanmasında önemli bir gösterge olarak kabul edilen varyasyon katsayısı $<\% 15$ düşük, \%15-35 orta ve $>35$ yüksek olarak sınıflandırılmaktadır (Mulla ve Mc Bratney 2000). Değişkenlik bakımından pH'nın düşük, bünye ve kalsiyumun orta, diğer bütün toprak özelliklerinin yüksek değişkenliğe sahip olduğu tespit edilmiştir. İç Anadolu Bölgesi topraklarının bünye, $\mathrm{pH}$, organik madde, tuz ve kireç içeriklerine göre dağılım haritaları Şekil 2'de verilmiştir. Bünye bakımından oransal olarak en fazla alanı killi tınlı topraklar (\%52.8) kapsamaktadır. Bunu sırası ile tınlı topraklar (\%23.1), killi topraklar (\%22.1), ağır killi topraklar $(\% 1.6)$ ve kumlu topraklar $(\% 0.4)$ izlemektedir. Toprak pH'sı bakımında en geniş alanı hafif alkali topraklar (\%89.2) kapsamaktadır. Bunu sırası ile nötr topraklar $(\% 8)$, hafif asit topraklar (\%1.4), kuvvetli alkali topraklar $(\% 1.1)$ ve orta derece asit topraklar (\%0.3) izlemektedir. Organik madde kapsamları bakımından ise bölge topraklarının \%21.3'ü organik maddece çok az, \%64.2'si az, $\% 11.5$ 'i orta, \%2.3'ü iyi ve \%0.7'si çok iyi sınıfındadır. Bölge topraklarının \%99.36'si tuzsuz, \%0.52'si hafif tuzlu, \%0.04‘ü orta tuzlu ve \%0.07'si ise çok tuzlu sinıfindadır. Kireç kapsamları bakımından ise bölge topraklarının \%25.4'ü çok fazla, $\% 30.7$ 'si fazla, $\% 28.2$ 'si orta, $\% 15.1$ 'i az ve $\% 0.6$ 's1 çok az kireçlidir.

İç Anadolu Bölgesi topraklarının yarayışlı makro elementler kapsamlarına göre dağılım haritaları Şekil 3'de verilmiştir. Bölge topraklarının \%21.5'i çok az, \%35.7'si az, \%18.2'si orta ve \%8.9'u fazla ve \%15.7'si çok fazla düzeyinde yarayışlı fosfor içerir. Yarayışlı potasyum bakımından ise İç Anadolu Bölgesi topraklarının \%0.5'i az, \%1.6's1 orta, \%3.5'i yeter ve \%94.4'ü fazla düzeydedir. İç Anadolu Bölgesi topraklarının $\% 0.8$ 'i az, \%4.4'ü yeterli, \%92.5'i fazla ve \%2.3'ü çok fazla düzeyinde yarayışlı kalsiyum içermektedir. Yarayışlı magnezyum bakımından ise bölge topraklarının \%0.2'si çok az, $\% 6.4$ 'ü az ve çok az, \%45.6'sı yeterli, \%45.9'u fazla ve \%1.9'u çok fazla düzeydedir.

Çizelge 1. İç Anadolu Bölgesi tarım alanlarından alınan toprak örneklerinin analiz sonuçlarına ait tanımlayıcı istatistikler.

Table 1. Descriptive statistics of the analysis results of soil samples taken from agricultural areas of Central Anatolia Region.

\begin{tabular}{|c|c|c|c|c|c|c|c|c|c|c|c|c|c|}
\hline & Bünye & $\mathrm{pH}$ & $\begin{array}{c}\text { Tuz } \\
\%\end{array}$ & $\begin{array}{c}\text { Kireç } \\
\%\end{array}$ & $\begin{array}{c}\text { Organik } \\
\text { Madde \% }\end{array}$ & $\begin{array}{c}\mathrm{P}_{2} \mathrm{O}_{5} \\
\mathrm{~kg} \mathrm{da}^{-1}\end{array}$ & $\begin{array}{c}\mathrm{K}_{2} \mathrm{O} \\
\mathrm{kg} \mathrm{da}^{-1}\end{array}$ & $\begin{array}{c}\mathrm{Ca} \\
\mathrm{ppm}\end{array}$ & $\begin{array}{c}\mathrm{Mg} \\
\mathrm{ppm}\end{array}$ & $\begin{array}{c}\mathrm{Fe} \\
\mathrm{ppm}\end{array}$ & $\begin{array}{c}\mathrm{Zn} \\
\mathrm{ppm}\end{array}$ & $\begin{array}{c}\mathrm{Cu} \\
\mathrm{ppm}\end{array}$ & $\begin{array}{c}\mathrm{Mn} \\
\mathrm{ppm}\end{array}$ \\
\hline En yüksek & 151.8 & 9.46 & 1.4119 & 84.73 & 8.13 & 133.79 & 737.87 & 16192 & 2763 & 76.3 & 33.01 & 39.8 & 76.9 \\
\hline En düşük & 28.6 & 4.5 & 0.0008 & 0.4 & 0.03 & 0.1 & 11.04 & 384.791 & 25.8 & 0.081 & 0.01 & 0.02 & 0.16 \\
\hline Ortalama & 61.16 & 7.77 & 0.03 & 18.16 & 1.47 & 7.79 & 120.30 & 6509.82 & 541.74 & 3.93 & 0.69 & 1.11 & 7.11 \\
\hline Basıklık & 2.68 & 16.06 & 611.58 & 1.74 & 10.33 & 48.60 & 6.68 & 3.06 & 1.87 & 67.70 & 177.74 & 501.91 & 31.24 \\
\hline Çarpıklık & 1.20 & -2.68 & 19.95 & 1.02 & 1.98 & 5.53 & 1.98 & 0.11 & 1.24 & 6.94 & 11.95 & 18.04 & 4.36 \\
\hline Ortanca & 59.35 & 7.79 & 0.02 & 17.07 & 1.38 & 5.30 & 99.87 & 6497.86 & 463.30 & 2.71 & 0.38 & 0.95 & 5.59 \\
\hline Standart Sapma & 16.22 & 0.38 & 0.04 & 12.46 & 0.66 & 9.35 & 77.18 & 1784.71 & 345.92 & 5.28 & 1.64 & 1.20 & 6.15 \\
\hline Varyans & 263.12 & 0.15 & 0.002 & 155.23 & 0.43 & 87.48 & 5957.49 & 3185205 & 119658 & 27.89 & 2.69 & 1.44 & 37.77 \\
\hline Varyasyon Katsayısı & 26.52 & 4.92 & 148.39 & 68.60 & 44.88 & 120.13 & 64.16 & 27.42 & 63.85 & 134.54 & 237.32 & 108.18 & 86.41 \\
\hline
\end{tabular}


İç Anadolu Bölgesi topraklarının yarayışlı mikro element kapsamlarına göre dağılım haritası Şekil 4‘de verilmiştir. Bölge topraklarının \%44.8'i az, \%32.2'si orta, \%23'ü iyi düzeyde yarayışlı demir içermektedir. Yarayışlı çinko kapsamları bakımından ise bölge topraklarının \%21.1'i çok az, \%54.2'si az, $\% 21.9$ 'u yeterli ve $\% 2.1$ 'i ise fazla ve \%0.7'si çok fazla düzeyindedir. Bölge topraklarının \%29.4'ü çok az, \%62.9'u az, $\% 7.3$ 'ü yeterli ve $\% 0.4$ 'ü ise fazla düzeyinde mangan içermektedir. Bölge topraklarının \%1.2'si yetersiz, \%98.8' $\mathrm{i}$ ise yeterli düzeyde bakır içermektedir.

\section{Tartışma ve Sonuç}

Bünye bakımından İç Anadolu Bölgesi topraklarının büyük kısmını (\%75.9) tarım için ideal olduğu kabul edilen ve potansiyel verim alımına uygun, tınlı ve killi tınlı topraklar oluşturmaktadır. Bölgedeki \%23.7 oranındaki killi ve ağır killi topraklarda tavın yakalanması ve dolayısıyla işlenmesi sorun oluşturmaktadır. Bu sorunu çözmek için uygulanabilecek en iyi yöntem, toprakların organik madde miktarını artırmak ve pulluk tabanını derin sürüm aletleriyle kırmaktır. Yapılacak sulama projelerinde, alet ekipman uygulamalarında ve alımlarında, toprağın bünye özelliğinin dikkate alınması faydalı olacaktır (Eyüpoğlu 1999).

Toprak reaksiyonu bakımından, İç Anadolu Bölgesi topraklarının en büyük kısmını (\%89.2) hafif alkali karakterdeki topraklar oluşturmaktadır. Alkali karakterli toprakların verimini artırmada başvurulacak ilk teknik tedbir, verimi büyük ölçüde azaltan yüksek toprak pH'sının, mikronize şekildeki toz kükürt ile iyi vasıflı ahır gübrelerinin birlikte uygulanarak düşürülmesi ve toprak pH'sını bitki besin elementlerinin alınabileceği en uygun $\mathrm{pH}$ aralığına getirmektir.
İç Anadolu Bölgesi topraklarının büyük bir kısmını (\%85.5) organik madde kapsamı az ve çok az olan topraklar oluşturmaktadır. Tarım bakımından ideal sayılan iyi ve yüksek organik maddeli toprakların toplam oranı, bölgede sadece \%3'tür. Bu verilerden de anlaşılacağı üzere, İç Anadolu Bölgesi topraklarının çok büyük bir çoğunluğunun organik madde kapsamı, tarımsal üretimden en yüksek verimin alınmasını engelleyecek düzeydedir. $\mathrm{Bu}$ nedenle bölge topraklarının organik madde seviyesinin yükseltilmesi gerekmektedir. Toprak organik madde düzeyinin iyileştirilmesi için ekim nöbetlerinde kullanılacak bitki çeşitlerine, sürüm tekniklerine ve ekim tekniklerine dikkat etmenin yanında organik gübrelerin yaygın kullanımına ve yeşil gübrelemeye özel önem verilmelidir.

İç Anadolu Bölgesi topraklarının çok büyük bir kısmı (\%99.36) tuzsuzdur ve bu tarım topraklarında arzu edilen bir durumdur. Tuzluluk, bitkisel üretimi engelleyen önemli bir etmendir ve tuzluluğun önlenmesi, 1slah etmekten daha ekonomik bir yöntemdir. Bunun için yapılan sulama projeleri, drenaj projeleri ile birlikte uygulanmalıdır.

Kireç kapsamı bakımından, İç Anadolu Bölgesi topraklarının büyük bir kısmı (\%56.1) fazla ve çok fazla düzeyinde kireç içermektedir. Yüksek kireç de tarımsal üretimi sınırlayan önemli bir etmendir. Pek çok araştırmacı, toprakların kireç içeriklerinin yüksek olmasının, başta fosfor ve çinko yarayışlılığı olmak üzere mikro elementlerin alınımını da güçleştirdiğini belirtmişlerdir (Udo ve ark. 1970; Mengel ve Kirkby 1982; Kacar ve ark. 1998). Bölgedeki çok fazla kireç içeren alanlarda, yetiştirilecek uygun anaç ve bitki çeşitlerinin seçilmesi önem taşımaktadır.

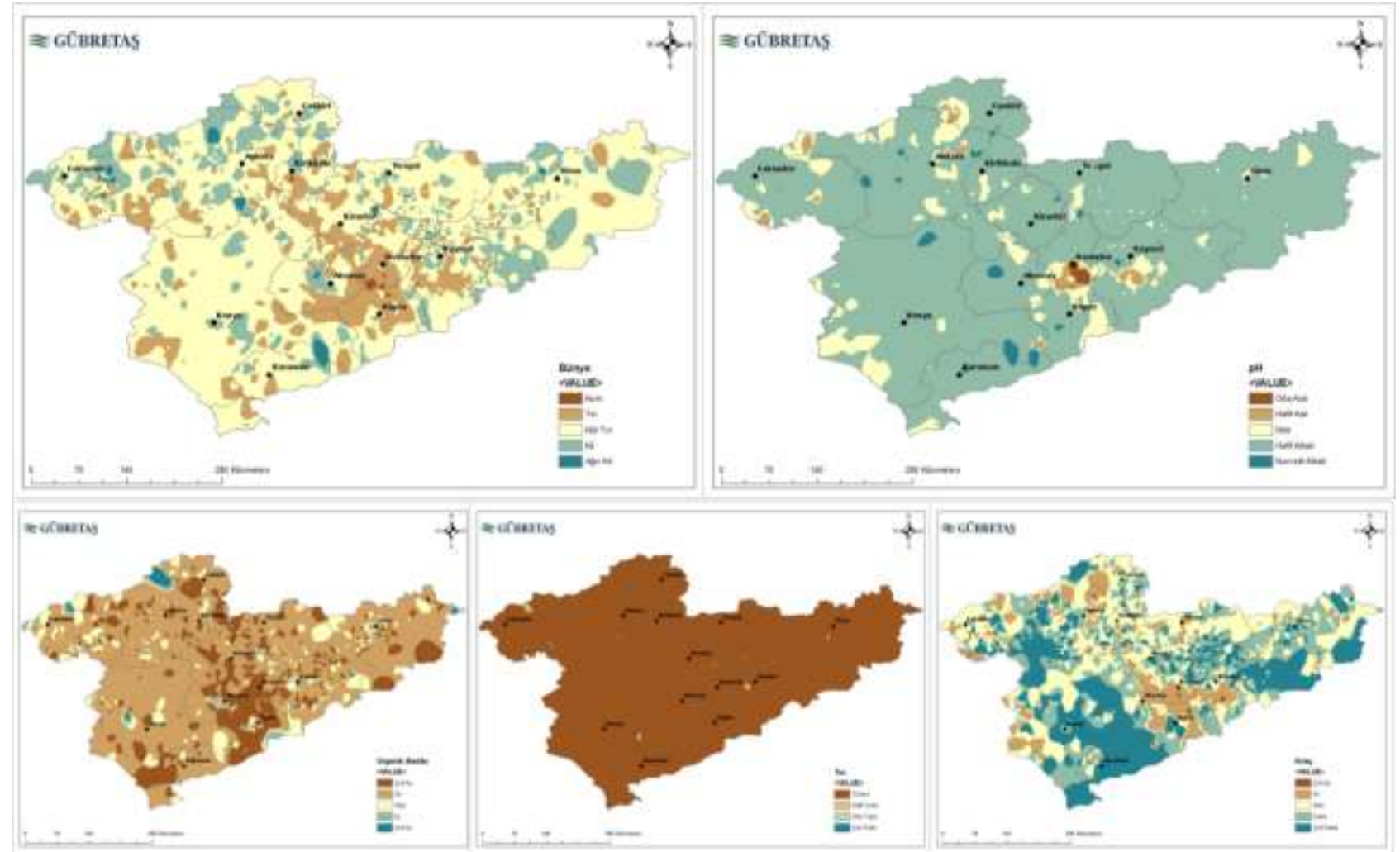

Şekil 2. İç Anadolu Bölgesi topraklarının bünye, pH, organik madde, tuz ve kireç dağılım haritaları.

Figure 2. Soil texture, $\mathrm{pH}$, organic matter, salinity and calcium carbonate distribution maps of Central Anatolia Region. 
İç Anadolu Bölgesi topraklarının büyük kısmının (\%75.4) yarayışlı fosfor kapsamı orta, az ve çok azdır. Bu alanlarda fosforlu gübrelemeye ihtiyaç vardır. Ayrıca kireçli ve yüksek pH'lı bölge topraklarında, fosfor fiksasyonu da mutlaka dikkate alınmalı ve fosforlu gübrelerin zamanında ve banta verilmesine özen gösterilmelidir. Mutlak gerekli bitki besin elementlerinden olan fosforun, tam ve gereğince uygulanabilmesi için toprak analizleri büyük önem taşımaktadır.

İç Anadolu Bölgesi topraklarının çok büyük bir kısmı (\%94.4) yarayışlı potasyum kapsamları bakımında yüksek, yarayışlı kalsiyum (\%99.2) ve yarayışlı magnezyum (\%93.4) bakımından yeterli, fazla ve çok fazla düzeyindedir. Bunun nedeni bölgedeki sıcak ve kurak iklim koşullarının yanında, bölgedeki düşük yağış nedeniyle, yıkanmanın olmamasıdır. Ayrıca, bitki besin elementlerinin dengesi bakımından ideal bir tarım toprağında $\mathrm{Ca} / \mathrm{Mg}=6, \mathrm{Ca} / \mathrm{K}=12, \mathrm{Mg} / \mathrm{K}=2$ olması beklenmektedir (Jokinen 1981). Bölge topraklarının $\mathrm{Ca} / \mathrm{Mg}$ oranlarının \%11.6's1, Ca/K oranlarının \%14.3'ü ve $\mathrm{Mg} / \mathrm{K}$ oranlarının \%37'si bu oranlara uymaktadır. Buradaki besin elementleri arasındaki dengenin bozulmasının nedeni toprak analizlerine dayanmayan tek taraflı ve dengesiz gübrelemedir.

İç Anadolu Bölgesi topraklarının yaklaşık yarısı (\%44.8) noksan düzeyde yarayışlı demir içermektedir. Demir noksanlığının görüldüğü alanlarda, demir içeren gübrelerin uygulanmasının yanında, kalsiyumun fazla olması nedeniyle ve havalanması uygun olmayan toprak şartlarında bitkiler demirden faydalanamayacakları için kloroz görülen alanlarda yapraktan demirli gübre uygulaması ayrıca önem kazanmaktadır.

Yarayışlı çinko kapsamları bakımından, bölge topraklarının büyük kısmında (\%75.3) noksanlık görülmektedir. Bu nedenle noksanlığın görüldüğü alanlarda, çinkolu ve çinko katkılı gübrelemeye önem verilmelidir.

İç Anadolu Bölgesi topraklarının büyük kısmında (\%92.3) yarayışlı mangan kapsamları bakımından noksanlık gözlenmektedir. Toprak analiz raporlarında mangan düzeyi az ve çok az olan bölgelerde, mangan içerikli gübrelerin uygulanması gereklidir.

Yarayışı bakır kapsamı yönünden ise bölge toprakları (\%98.8) yeterli düzeydedir. İç Anadolu Bölgesi topraklarının yarayışlı bakır kapsamı, kritik değer kabul edilen $0.2 \mathrm{mg} \mathrm{kg}^{-1}$ 'in (Follett 1969) üstündedir ve bakır noksanlığı mevcut değildir.

İncelenen toprak özelliklerinin ve besin elementi durumlarının saptanması, gübre üretim planlamalarının ve gübre tüketim politikalarının belirlenmesinde, önemli bir kaynak oluşturmaktadır. Bitki besin maddeleri bakımından fazlalık, yeterlilik ve noksanlık seviyelerinin belirlenmesi, aynı zamanda sürdürülebilir tarım politikaları bakımından da büyük önem taşımaktadır. Kullanılan coğrafi bilgi sistemleri teknikleri ise elde edilen sonuçların, düzenli ve sistemli olarak bir veri tabanında toplanmasını, eklenecek yeni verilerle yeniden yorumlanabilmesini ve oluşturulan tematik haritalarla, noktasal verilerin alansal verilere dönüştürülmesini sağlamaktadır.

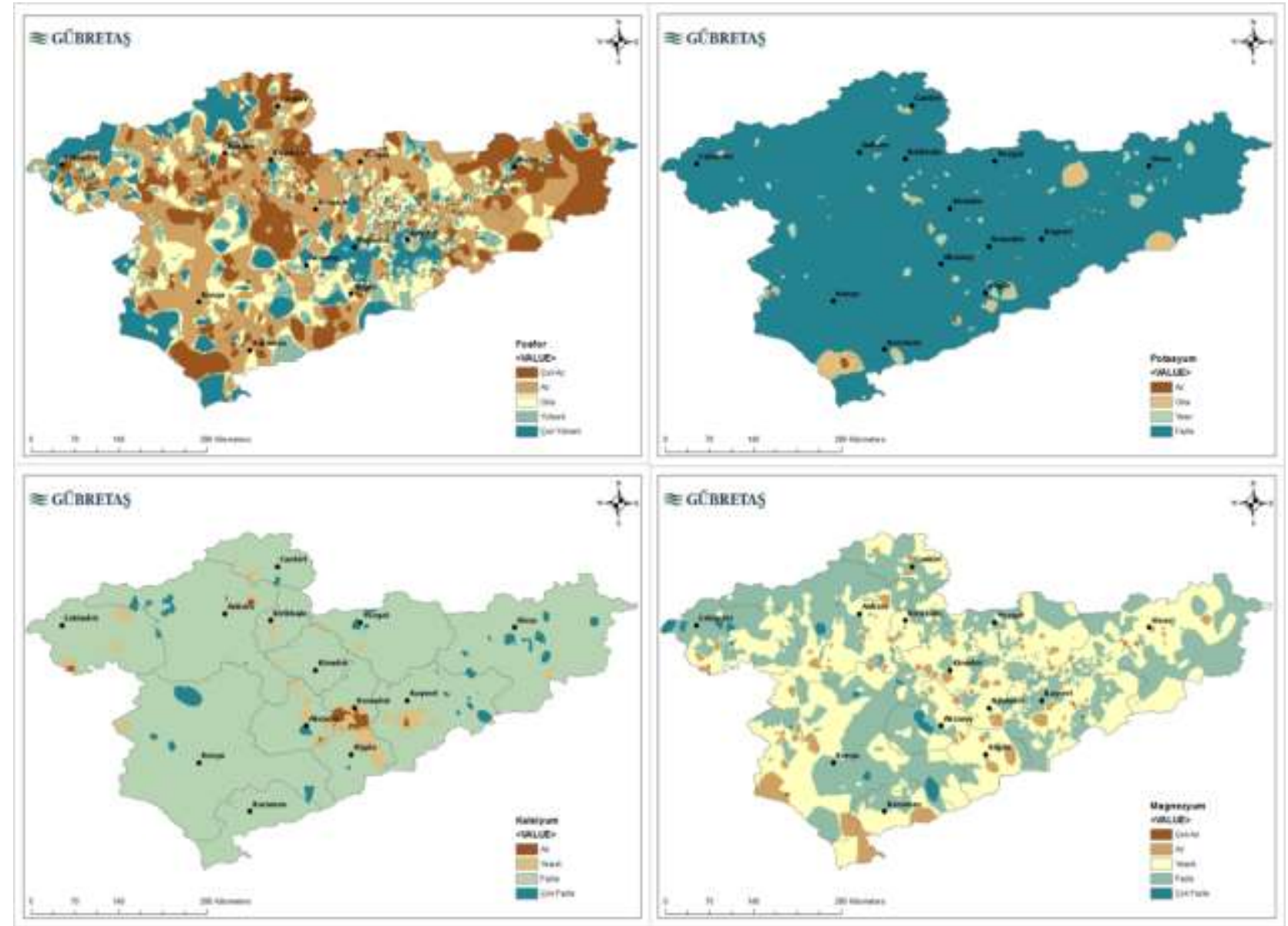

Şekil 3. İç Anadolu Bölgesi topraklarının yarayışılı makro elementler dağılım haritaları.

Figure 3. Available macro elements distribution maps of Central Anatolia Region. 


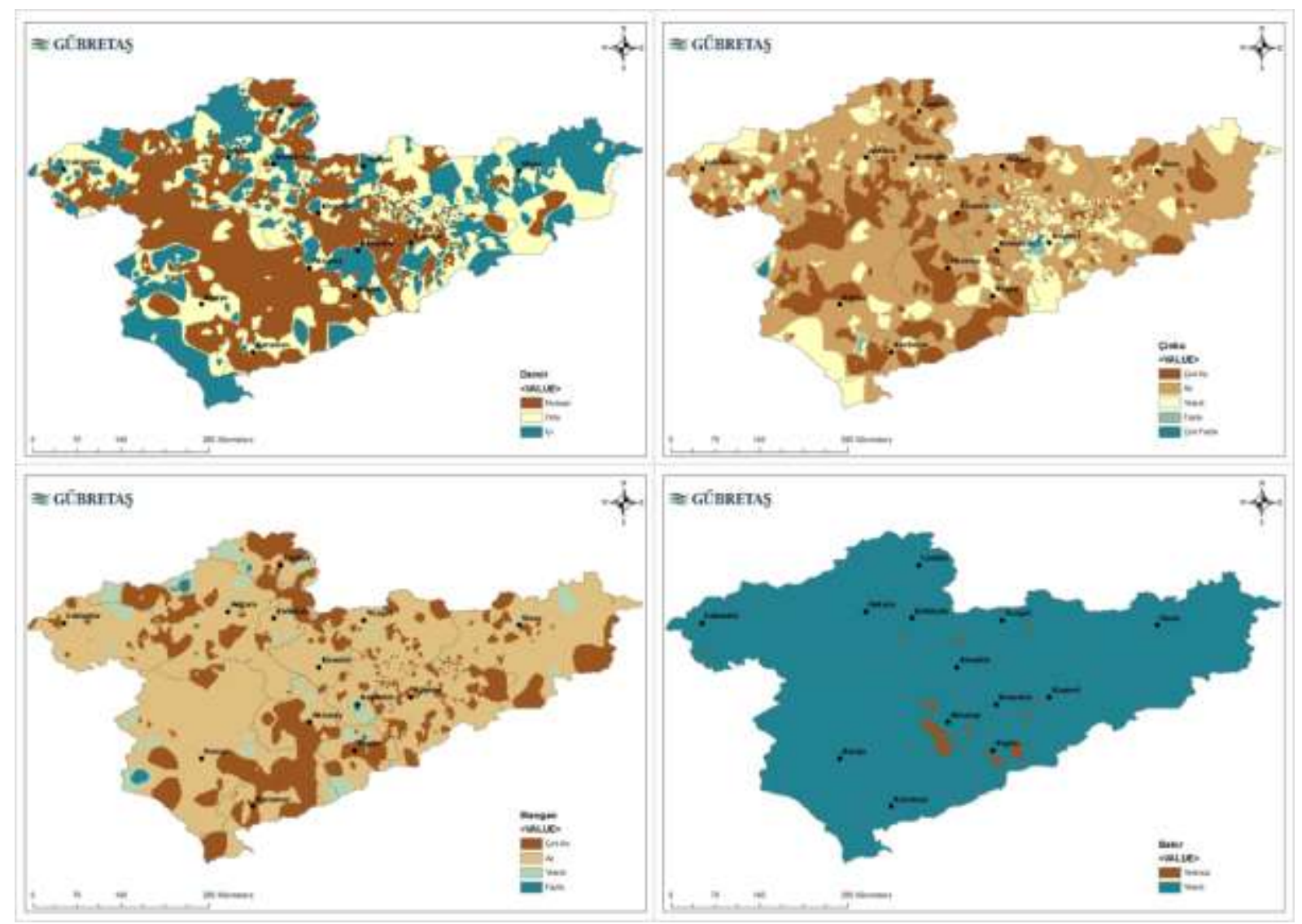

Şekil 4. İç Anadolu Bölgesi topraklarının yarayışlı mikro elementler dağılım haritaları.

Figure 4. Available micro elements distribution maps of Central Anatolia Region.

\section{Kaynaklar}

Çağlar K (1949) Toprak Bilgisi. Ankara Üniversitesi Ziraat Fakültesi Yayınları No: 985, Ankara.

Eyüpoğlu F (1999) Türkiye Topraklarının Verimlilik Durumu. T.C. Başbakanlık Köy Hizmetleri Genel Müdürlüğü. Toprak ve Gübre Araştırma Enstitüsü Yayınları, Genel Yayın No: 220, Teknik Yayın No: T-67.

Follett RH (1969) Zn, Fe, Mn and Cu in Colorado Soils. PhD Thesis, Colorado State University, Colorado.

Jackson ML (1958) Soil Chemical Analysis. Prentice-Hall, Inc. Englewood Cliffs, N.J.

Jokinen R (1981) The Magnesium Status of Finnish Mineral Soils and The Requirement of The Magnesium. Magnesium-Bulletin 3(1a): $1-5$.

Kacar B, Taban S, Alpaslan M, Fuleky G (1998) Zinc Phosphorus Relationship in The Dry Matter Yield and The Uptake of Zn, P, Fe and Mn of Rice Plants (Oryza sativa L.) as Affeeted by The Total Carbonate Content of The Soil. Second International Zinc Symposium. Abstracts, Ankara, pp. 20.

Kacar B (2009) Toprak Analizleri. 2.Bask1, Ankara Üniversitesi Ziraat Fakültesi Yayınları, Ankara.

Lindsay WL, Norwell WA (1978) Development of a DTPA Soil Test For Zinc, İron, Manganese and Copper. Soil Sci. Amer. Jour. 42(3): 421-428.

Mengel K, Kirkby EA (1982) Principles of Plant Nutrition. $3^{\text {rd }}$ Edition, International Potash Institute, P.O. Box. CH-3048 WorblaufenBern, Switzerland, pp. 655.

Mulla DJ, Mc Bratney AB (2000) Soil Spatial Variability. Handbook of Soil Science. CRS Press, pp. 321-352.
Olsen SR, Cole V, Watanabe FS, Dean LA (1954) Estimation of Available Phosphorus in Soils by Extraction With Sodium Bicarbonate. U.S.D.A.

Özyazıcı MA, Dengiz O, Aydoğan M, Bayraklı B, Kesim E, Urla Ö, Yıldız H, Ünal E (2015) Orta ve Doğu Karadeniz Bölgesi tarım topraklarının bazı makro ve mikro bitki besin maddesi konsantrasyonları ve ters mesafe ağırlık yöntemi (IDW) ile haritalanması. Artvin Çoruh Üniversitesi Orman Fak. Dergisi Cilt No: 16, Say1: 2, s. 187-202.

Richards LA (1954) Diagnosis and Improvement Saline and Alkaline Soils. Handbook 60, U.S.D.A.

TOVEP (1983, 1984, 1985) Ankara, Çankırı, Eskişehir, Kayseri, Kırşehir, Konya, Nevşehir, Niğde, Sivas ve Yozgat İlleri Verimlilik Envanteri ve Gübre İhtiyaç Raporu. T.C. Tarım Orman ve Köy İşleri Bakanlığı Toprak Su Genel Müdürlüğü Yayınları, Ankara.

TOVEP (1991) Türkiye Toprakları Verimlilik Envanteri. T.C. Tarım ve Orman Köy İşleri Bakanlığı, Köy Hizmetleri Genel Müdürlüğü.

TÜİK (2018) Bitkisel Üretim İstatistikleri. İstatistiksel Tablolar. Tarım Alanları.

http://www.tuik.gov.tr/PreIstatistikTablo.do?istab_id=1561. Erişim 14 Aralık 2018.

Udo EJ, Bohn HL, Tucker TC (1970) Zinc Adsorption by Calcareous Soils. Soil Sci. Soc. Am. J 34: 405-410.

Ülgen N, Yurtsever N (1995) Türkiye Gübre ve Gübreleme Rehberi (4. Bask1). T.C. Başbakanlık Köy Hizmetleri Genel Müdürlüğü. Toprak ve Gübre Araştırma Enstitüsü Yayınları, Genel Yayın No: 209, Teknik Yayın No: T-66.

Yomralığlu T (2000) Geographical Information Systems. Academy Presses. Trabzon, Turkey. 